\title{
Customer Impulse Buying Behavior in Kathmandu
}

\author{
Sajeeb Kumar Shrestha, PhD* \\ Received on 5 September 2018; Revised on 3 November 2018; Accepted on 7 December 2018
}

\begin{abstract}
This study examines customer impulse buying behavior in Kathmandu for the retail sector. Departmental store located in Kathmandu City were approached and collected data. Judgmental sampling technique was used and data were collected from 250 samples. Descriptive statistics and multiple regression analysis were used to summarize the nature of data and to test the hypotheses. The research confirmed that window display, in-store display and promotional signage had significanct influence on impulse buying of customers. No support was found for floor merchandising.
\end{abstract}

Keywords: Impulse buying, Kathmandu, window display.

\section{INTRODUCTION}

Impulse buying is an instant buying when customer quickly decides to purchase the product without following the consumer buying process. As customer sees the products suddenly buy it. More purchases are done through impulse buying. Impulse buying is a kind of hedonic type that is more convincing (Kacen \& Lee, 2002).

Impulse purchasing is a phenomenon by which a consumer experiences a sudden and often persistent urge to buy something immediately (Hoch \& Loewenstein, 1991; Parboteeah, 2005; Rook, 1987; Rook \& Gardner, 1993). Beatty and Ferrell (1998) argue impulse purchase is an immediate purchase with no pre-shopping intention. Rook (1987) suggests impulse buying occurs when a consumer experiences a sudden and often persistent urge to buy something immediately. Piron $(1991,1993)$ defines impulse purchase as an unplanned purchase. Marketers should promote a good store layout to maximize the convenience of the consumer (Crawford \& Melewar, 2003). Impulse buying is a reason for increasing more sales (Bellenger, Robertson, \& Hirschman, 1978). It is an expected buying that a retailer does not plan earlier.

The impulse buying behavior of consumers are recognized by the retailers and they use to design their shops' layouts, shelving, branding and much more to attract the consumer or shopper to influence them to make impulse buying and generate revenues. This phenomenon has been tremendously increasing during the last decade and the companies are working on the store environment and collecting information and doing research on how they can influence consumers' impulse buying behavior (Bhatti \& Latif, 2013).

Window display is a major marketing tool motivates a customer to enter into the outlet (Jiyeon, 2003). It includes any kind of visual presentation of the store that attracts the attention of the customer.

In-store display/mannequin display permits customers to see the products in the store (Iqba, Umer, Mqbool, \& Sunil, 2011). It can be designed as merchandize display, artistic display and point of sale

* Dr. Shrestha is Lecturer in Shanker Dev Campus, TU, Kathmandu.E-mail: drsajeeb@gmail.com 
display (cited in Kerfoot, Davies, \& Ward, 2003). It supports planned and unplanned purchase (BastowShoop, Zetocha, \& Passewitz, 1991). Customers are motivated by attracted displays within three to eight seconds (Bastow-Shoop et al., 1991).

Floor merchandising is the in-store product display, how the product is arranged in the shelves, and point of sale display. It makes convenience to customers for product selection. Customers missed one third of the product on the shelves while selecting it (Young, Kwon, \& Lennon, 2007).

Promotional signage is communication messages delivered to customers to inform and created demand for products in the store (Jiyeon, 2003). Product messages like low prices, sale-sale offer and heavy discounts (Stern, 1962). In store advertising and point of sale display influence 53 to 60 percent of customer purchase (Hubrechts \& Kokturk, 2012).

Mehta and Chugan (2013) found window display; floor merchandising and promotional signage had a significant effect on impulse buying. But, In-store form/mannequin display did not influence on impulse buying behavior. Khandai (2012) found window display and in-store/mannequin affect customer's impulse buying behavior having a significant effect.

Moayery, Zamani, and Vazifehdoost (2014) declared winnow display, in-store display/mannequin display and promotional signage directly affect apparel impulse buying although cross-merchandising. Floor merchandising did not influence customer's impulse buying.

This paper focuses on answering the following questions: What is the influence of window display, in-store display/mannequin display, floor merchandising and promotional signage on impulse buying behavior? The objective of the paper is to analyze the effect of the window display, in-store display/ mannequin display, floor merchandising and promotional signage on impulse buying.

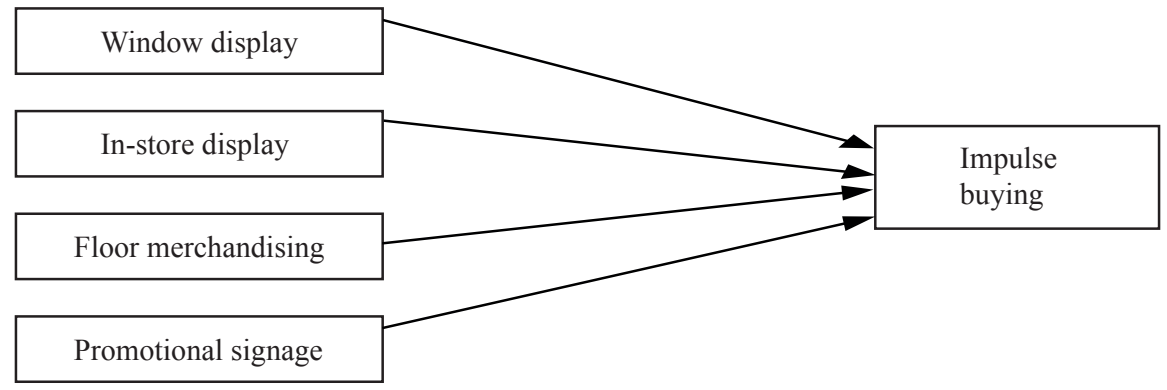

Figure 1. Conceptual framework

\section{DATA AND METHODS}

The main objective of this research is to examine the customer's impulse buying behavior at Kathmandu City. To carry out this research descriptive research and causal research design was used (Malhotra \& Birks, 2006). The main focus of descriptive design is to describe thoroughly the research construct related to marketing (Malhotra \& Birks, 2006; Zikmund, 2000).

The population of the study was the customers who shop at the departmental store in Kathmandu City. Judgmental sampling was taken as shoppers who come for purchase in the departmental stores with or without having purchase intention and for fun. Two hundred fifty samples were collected during the data collection period of one month (Eldred, 1987; Kline, 2011). Sample size more than 200 is called a large sample that is sufficient to yield useful results (Eldred, 1987).

Structured questionnaires based on Likert scales were used to collected data from shoppers. For the 
collection of data, everyday twelve to six o'clock time was allocated because many people shop the departmental stores at day time or after office time. So, to meet the target people this time was managed by the researcher.

Reliability analysis was done to check the consistency of the questionnaires. Descriptive statistics was done to summarize the theme of data. Multiple regression analysis was run to test the hypotheses proposed in this research.

Fifty-seven percent respondents were male and 43 percent respondents were female. Majority of respondents were between 20 to 40 years and 40 to 60 years accounting of 72 percent of both in total. Fifty two percent of the respondents have completed a bachelor degree and 20 percent completed their master degree. Fifty eight percent respondents were employee while 18 percent were housewives.

The study used following model:

$\mathrm{IB}=\alpha+\beta 1 \mathrm{WD}+\beta 2 \mathrm{ISD}+\beta 3 \mathrm{FM}+\beta 4 \mathrm{PS}+\varepsilon \mathrm{i}$

Where, $\alpha=$ Constant; $\beta \mathrm{i}=$ Coefficients of independent variables; $\varepsilon \mathrm{i}=$ Error term, IB $=$ Impulse Buying, WD = Window display; ISD = In-store form/display; FM = Floor merchandising; and PS = Promotional signage.

\section{Hypothesis}

The Hypothesis is proposed as follows:

H1: Window display has a significant influence on impulse buying.

H2: In-store form/mannequin display has a significant influence on impulse buying.

H3: Floor merchandising has a significant influence on impulse buying.

H4: Promotional signage has a significant influence on impulse buying.

This research has some limitations. The study analyses the impulse buying behavior of customers in Kathmandu City only. Primary data were collected in this research. Therefore, the reliability of the findings depends upon the accuracy of the information provided by the respondents.

\subsection{Reliability Analysis}

\section{RESULTS AND DISCUSSION}

Reliability analysis is done to confirm the internal consistency of the questionnaires or survey instruments. Alpha value greater than 0.7 represents the standard of scales items to be used for the survey (Nunnally \& Bernstein, 1994).

Table 1

Reliability Analysis

\begin{tabular}{clc}
\hline Code & Construct & Cronbach's Alpha \\
\hline WD & Window display & .726 \\
ISD & In store display & .792 \\
FM & Floor merchandising & .764 \\
PS & Promotional signage & .784 \\
IB & Impulse buying & .733 \\
\hline
\end{tabular}


Table 1 highlights the reliability of the scales items of constructs. Cronbach's Alpha coefficients of all the constructs are greater than 0.7 so it shows excellent fit (George \& Mallery; Nunnally \& Bernstein, 1994).

\subsection{Descriptive Analysis}

Descriptive statistics are used to report and summarize the basic nature of the data. Mean and standard deviation is the key tools in the descriptive analysis for average and variation in the collected data. It is presented in Table 2.

Table 2

Descriptive Analysis

\begin{tabular}{lcc}
\hline \multicolumn{1}{c}{ Construct } & Mean & Standard deviation \\
\hline Window display (WD) & 3.66 & .36 \\
In store display (ISD) & 3.74 & .97 \\
Floor merchandising (FM) & 3.94 & .34 \\
Promotional signage (PS) & 4.11 & .45 \\
Impulse buying (IB) & 3.07 & .45 \\
\hline
\end{tabular}

Table 2 shows the mean value of window display, in-store display, floor merchandising, promotional signage and impulse buying were above 3 . It is viewed as customers were influenced by these constructs while making purchase instantly.

\subsection{Regression Analysis}

Regression assumptions were tested before running the regression analysis. Normality, linearity, multicollinearity, and independence of error tests showed no problems on data. So, regression analysis was run.

Table 3

Regression Analysis

\begin{tabular}{lcc}
\hline Explanatory variable & Coefficient value of B & p-value \\
\hline (Constant) & .540 & .000 \\
Window display (WD) & .235 & .000 \\
In store form/display (ISD) & .071 & .040 \\
Floor merchandising (FM) & .082 & .065 \\
Promotional signage (PS) & .063 & .000 \\
\hline $\mathrm{R}=0.46788 ; \mathrm{R}^{2}=0.583 ;$ Adjusted R ${ }^{2}=0.564 ;$ Std. Error of the estimate $=0.6714 ;$ \\
F-Value $=125.24 ;$ p-value of F test $=0.000$. & \\
Sig. at $5 \%$ level & \\
Model: IB $=.54+0.235$ WD +0.071 ISD +0.082 FM +0.063 PS & \\
\hline
\end{tabular}


Table 3 shows F-value and p-value of regression model was 125.24 and 0.000 respectively, which is significant at $5 \%$ level of significance. So, the model fitted well.

$\mathrm{R}$ square of this model was 0.583 which denotes the model predicts 58.3 percent in impulse buying by variation of explanatory variables (window display, in-store display, floor merchandising, and promotional signage).

\subsection{Hypothesis Testing}

H1: $\quad$ Window display has a significant influence on impulse buying.

Sig. value of window display is 0.000 that is significant at $5 \%$ level of significance. So, H1 is accepted. Window display has significant influence on impulse buying.

H2: $\quad$ In-store form/mannequin display has significant influence on impulse buying.

Sig. value of in-store form/mannequin display is 0.040 that is significant at $5 \%$ level of significance. So, $\mathrm{H} 2$ is accepted. In-store display has significant influence on impulse buying.

H3: $\quad$ Floor merchandising has significant influence on impulse buying.

Sig. value of in-store form/mannequin display is 0.065 that is not significant at $5 \%$ level of significance. So, H3 is not accepted. Floor merchandising has no significant influence on impulse buying.

H4: $\quad$ Promotional signage has significant influence on impulse buying.

Sig. value of promotional signage is 0.000 that is significant at $5 \%$ level of significance. So, H4 is accepted. Promotional signage has significant influence on impulse buying.

\section{CONCLUSION}

The research was conducted to examine the customer's impulse buying behavior in Kathmandu in the retail sector. This research confirmed that window display, in-store display, and promotional signage have a significant influence on impulse buying. No support was found for floor merchandising. This study is consistent with Mehta and Chugan (2013), Khandai (2012) and Moayery, Zamani and Vazifehdoost (2014) that window display, in-store display and promotional signage had important factors for creating impulse buying. Window display creates appeal to the potential customers to enter into the store. In-store display motivates customers catching their eyes. Floor merchandising is arranging the products in the shelves and racks and promotional signage gives opportunity to customers for instant buying. In this regard, retailers should design window display attractively, design in-store display so tactfully that it will catch the eyes of the customers, floor merchandising helps customer involvement in product evaluation and selection and promotion signage give the opportunity to purchase instantly.

\section{REFERENCES}

Bastow-Shoop, H., Zetocha, D., \& Passewitz, G. (1991). Visual merchandising: A guide for small retailers. IOW: University Publications.

Beatty, S. E., \& Ferrell, M. E. (1998). Impulse buying: Modeling its precursors. Retailing, 74, 169-191.

Bellenger, D. N., Robertson, D. H., \& Hirschman, E. C. (1978). Impulse buying varies by products. Journal of Advertising Research, 18(6), 15-18.

Bhatti, K. L., \& Latif, S. (2013). The impact of visual merchandising on consumer impulse buying behavior. 
Proceedings of 4th Asia-Pacific Business Research Conference, Bayview Hotel, Singapore.

Crawford, G., \& Melewar, T. C. (2003). The importance of impulse purchasing behavior in the international airport environment. Journal of Consumer Behavior, 3(1), 85-98.

Eldred, G. (1987). Real estate: Analysis and strategy. New York: Harper \& Row.

George, D., \& Mallery, P. (2009). SPSS for Windows, step by step ( $8^{\text {th }}$ ed.). Delhi: Dorling Kindersley.

Hoch, S. J., \& Loewenstein, G. F. (1991). Time-inconsistent preferences and consumer self-control. Journal of Consumer Research, 17, 492-507.

Hubrechts, L., \& Kokturk, B. (2012). Effects of visual merchandising on young consumers 'impulse buying behavior (Bachelor Dissertation). School of Business and Engineering, Halmstad University, Sweden.

Iqba, A., Umer, H., Maqbool, A., \& Sunil, N. (2011). Design, effectiveness and role of visual merchandising in creating customer appeal. Retrieved from http://mpra.ub.unimuenchen. de/30365/1/MPRA_paper_30365. pdf

Jiyeon, K. (2003). College students' apparel impulse buying behaviors in relation to visual merchandising (Graduate dissertation), The University of Georgia. Retrieved from https://getd.libs.uga.edu/pdfs/kim jiyeon_200308_ms.pdf

Kacen, J. J., \& Lee, J. A. (2002). The influence of culture on consumer impulsive buying behavior. Journal of Consumer Psychology, 12(2), 163-176.

Kerfoot, S., Davies, B., \& Ward, P. (2003). Visual merchandising and the creation of discernible retail brands. International Journal of Retail \& Distribution Management,31(3), 143-152.

Khandai, S. (2012). Visual merchandising as an antecedent to impulse buying: An Indian perspective. International Journal of Business and Management Studies, 1(1), 267-277.

Kline, R. B. (2011). Principles and practice of structural equation modeling ( $3^{\text {rd }}$ ed.). New York: The Guilford Press.

Malhotra, N. K., \& Birks, D. F. (2006). Marketing research: An applied approach (2 ${ }^{\text {nd }}$ European ed.). Harlow: Financial Times, Prentice Hall.

Mehta, N. P., \& Chugan, P. K. (2013). The impact of visual merchandising on impulse behavior of consumer: A case from Central Mall of Ahmedabad India. Universal Journal of Management, 1(2), 76-82.

Moayery, M., Zamani, S., \& Vazifehdoost, H. (2014). Effect of visual merchandising on apparel impulse buying behaviors among Iranian young adult females. Indian Journal of Science of Technology, 7(3), 360-366.

Nunnally, J. C., \& Bernstein, I. H. (1994). Psychometric theory (3 $3^{\text {rd }}$ ed.). New York: McGraw-Hill Inc.

Parboteeah, D. V. (2005). A model of online impulse buying: An empirical study (Doctoral dissertation), Washington State University. Retrieved from http://citeseerx.ist.psu.edu/viewdoc/ download?doi=10.1.1.425.4182\&rep=rep1\&type $=$ pdf

Piron, F. (1991). Defining impulse purchasing. Advances in Consumer Research, 18, 509-514.

Piron, F. (1993). A comparison of emotional reactions experienced by planned, unplanned and impulse purchasers. Advances in Consumer Research, 20, 341-344.

Rook, D. W., \& Gardner, M. P. (1993). In the mood: Impulse buying's affective antecedents. Research in Consumer Behavior, 6(7), 1-28.

Rook, D. W. (1987). The buying impulse. Journal of consumer research, 14, 189- 199.

Stern, H. (1962). The significance of impulse buying today. Journal of Marketing, 26, 59-63.

Young, H., Kwon, W., \& Lennon, K. (2007). Online visual merchandising (VMD) of apparel websites. Journal of Fashion Marketing and Management, 11(4), 477-493.

Zikmund, W. G. (2000). Business research methods. Fort Worth: The Dryden Press. 